\title{
Kanser Tanılı Hastanın Merley Mishel'in Hastalıkta Belirsizlik Kuramına Göre Hemşirelik Bakımı: Olgu Sunumu
}

\author{
Derya Çınar ${ }^{1}$, Yasemin Yıldırım² $\odot$, Fisun Şenuzun Aykar²®
}

'İzmir Bakırçay Üniversitesi Sağlık Bilimleri Fakültesi, Hemşirelik Bölümü, İzmir, Türkiye Ege Üniversitesi, Hemşirelik Fakültesi, İzmir, Türkiye

Derya Çınar, Dr. Öğr. Üyesi Yasemin Yıldırım, Prof. Dr. Fisun Şenuzun Aykar, Prof. Dr.

İletişim:

Dr. Öğr. Üyesi Derya Çınar İzmir Bakırçay Üniversitesi Sağlık Bilimleri Fakültesi, Hemşirelik Bölümü, Izmir, Türkiyee Tel: +90 2662459595

E-Posta: deryacinar73@hotmail.com

Gönderilme Tarihi : 04 Kasım 2018

Revizyon Tarihi : 08 Mart 2019

Kabul Tarihi : : 03 Mayıs 2019
ÖZET

Kanser tanısı almak, sınırlı ve sarsıcı tedavi seçenekleri, yaşanan kayıplar, nüksetme korkusu ve belirsiz bir ömür beklentisi hastaların bilinmezlik yaşamalarına ve yüksek belirsizlik deneyimlemelerine neden olabilir. Belirsizlik kanser deneyiminin önemli bir bileşenidir ve hastanın hastalık durumunun sonuçlarını dramatik bir şekilde etkileyebilir. Mishel'in Hastalıkta Belirsizlik Hemşirelik Kuramı; hastalıklarda kavramsal bir çerçeve olarak belirsizliği sunarak, bütüncül bakıma temel oluşturmakta ve rehberlik etmektedir. Hastalıkta Belirsizlik Teorisi, hastadaki belirsizliği gidermeye ve başa çıkma mekanizmalarını kullanmalarına yardımcı olan bir yaklaşımdır. Hastalığa ilişkin belirsizliğin yönetimine katkı sağlamak amacıyla hemşirelerin rolü; süreci kolaylaştırmak, hastanın sağlıklı tepkilerle daha da güçlenmesini sağlamaktır.

Bu olgu sunumunda; Mishel'in Hastalıkta Belirsizlik Hemşirelik Kuramı kapsamında Palyatif Bakım Ünitesi'nde Over Kanseri tanısıyla yatan 66 yaşındaki bir kadın hastada hemşirelik bakım süreci planlanmıştır. Aynı zamanda; destekleyici ve bütüncül hemşirelik yaklaşımları ve rehberliğine olanak sağlayan bu kuramın klinik olarak uygulanabileceği paylaşılmıştır.

Anahtar sözcükler: Belirsizlik, hemşirelik, kanser

NURSING CARE OF PATIENT WITH CANCER DIAGNOSIS ACCORDING TO MERLE MISHEL'S THEORY OF UNCERTAINTY IN ILLLESS: A CASE REPORT

\section{ABSTRACT}

Diagnosis of cancer, limited and shocking treatment options, the experience of loss, fear of recurrence and an uncertain life expectancy can lead patients to experience obscurity and high uncertainty. Uncertainty is an important component of the cancer experience and can dramatically affect the results of the patient's illness. Mishel's Uncertainty in IIIness Theory; by providing uncertainty as a conceptual framework in diseases, it forms the basis and provides guidance for holistic care. The Uncertainty in Illness Theory (UIT) is an approach that helps to eliminate uncertainty in the patient and use coping mechanisms. The role of nurses to contribute to the management of uncertainty related to the disease; is to facilitate the process, to strengthen the patient with healthy responses.

In this case report; a nursing care process was planned in a 66-years-old female patient with the diagnosis of Ovarian Cancer treated in the Palliative Care Unit within the scope of Mishel's Uncertainty in Illness Nursing Theory. At the same time; this theory, which allows for supportive and holistic nursing approaches and guidance, is intended to be easily applied clinically.

Keywords: Cancer, illness, nursing 
$\mathbf{P}$ alyatif bakım sürecinde hastaların ağrı ve diğer semptomlarının kontrol altına alınması, fiziksel, psikososyal ve spiritüel gereksinimlerinin karşılanması, yaşam kalitelerinin yükseltilmesi palyatif bakımın temel hedeflerindendir (1). Dünya Sağlık Örgütü palyatif bakımı "Yaşamı tehdit eden durumlarla birlikte görülen sorunlarla karşı karşıya olan hastaların ve ailelerin yaşam kalitesini, ağrıyı ve fiziksel, psikososyal ve spiritüel (manevi) boyuttaki diğer sorunları erken dönemde belirleyerek, kusursuz bir biçimde değerlendirerek ve tedavi ederek geliştiren bir yaklaşım" olarak tanımlamaktadır $(2,3)$. Kanserin tanı, tedavi ve yas sürecini de içine alan tüm aşamalarında destek gereksinimi palyatif bakım sürecinde daha da öne çıkmaktadır (1).

Kanser hastalar için bir stresördür ve hastalığa yüklenen anlam kaygı yaratır. Kanser tanısı alan hastalar ve yakınları prognozu belli olmayan bilinmezlik ve çaresizlik içindedirler. Belirsizlik ve bilinmeyen durum bireyler için her zaman ürkütücüdür. Sonunun ne olacağını bilmeden beklerken yaşanılan belirsizlik, ne olduğu bilinen kötü bir sonuçla yüz yüze gelmekten daha sıkıntı verici ve yıpratıcıdır.

Hemşirelik kuramları, hemşireliğin temel kavramları ve kavramlar arası ilişkileri tanımlayan, analiz ve sentez yoluyla sistematik bir görüş kazandıran, uygulamaları destekleyen, organize eden, kolaylaştıran ve rehberlik eden bilimsel çerçevedir (4). Kuramlar, hemşirelik bakımının bilimsel yapısını geliştirmeye katkı sağlayan araştırma çalışmaları için mesleki kuramsal bir çatı oluştururlar. Bu sayede araştırma sonuçlarının uygulama alanlarına aktarılması ve klinik sonuçların bakıma yansıtılmasına olanak sağlarlar.

Merle Mishel tarafından 1988 yılında "Hastalıklarda Belirsizlik Kuramı (HBK)", hemşirelik uygulamalarında ve araştırmalarında kullanılmak üzere, hastaların sıklıkla yaşadıkları belirsizlik durumunu tanımlamak ve açıklamak amacıyla geliştirilmiştir (5-9) (Şekil 1). Hastalıklarda Belirsizlik Kuramı hastalıkların tanı öncesi, tanı ve tedavi fazında kullanıma uygundur. Kuram kronik hastalıklarda kullanılmak üzere 1990 yılında Mishel tarafından tekrar kavramsallaştııılmıştır (9). Mishel'e göre belirsizlik; olayları anlamlandırmada yetersiz kaldığında, karar verici olduğu durumdayken nesnelere veya olaylara belirli bir değer veremediğinde veya sonuçları önceden tahmin edemediğinde ortaya çıkabilir. Kronik hastalıklarda belirsizlik; hastalık etyolojisi, semptomlar ve tedavi seçeneklerine ilişkin netlik eksikliğidir (9). Kuram, bireylerin hastalıklardan nasıl anlam çıkardıklarını açıklar. Kanser ve kronik hastalıkların nasıl dengesizlik yarattığını, insanların hastalığa yeni anlam bulmak için belirsizliği nasıl benimsediklerini daha gerçekçi ortaya koyabilmeyi amaçlamaktadır. Modelin teorik çerçevesi belirsizliktir. Hastalıklarda Belirsizlik Kuramı kavramları 3 temel tema çerçevesinde doğrusal bir modelde organize edilmiştir:

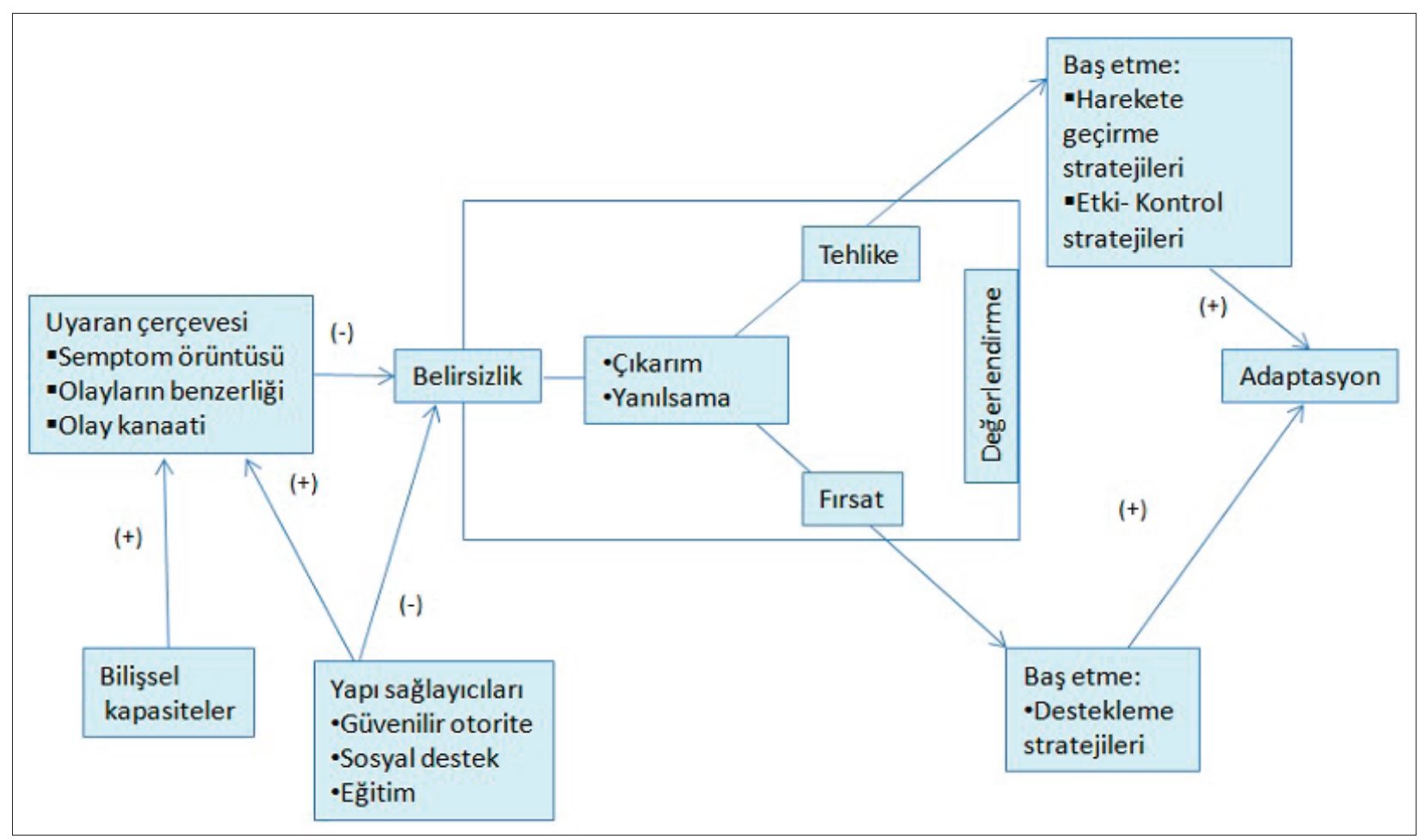

Şekil 1. Mishel'in HBK teorik modeli (6-9). 


\section{Yaşanan belirsizlik öncesi durum / Belirsizlik öncüleri}

Hastalık deneyiminden önce ortaya çıkan, ağrı, önceki deneyimler ve algı gibi hastanın düşüncelerini etkileyen her şey.

Uyaran çerçevesi, kişinin algısını uyaran herhangi nesne ya da olaylara özgü özelliktir.

Bilişsel kapasite, hastanın bilgiyi değerlendirme sürecidir ve hem doğuştan gelen becerileri hem de kısıtlayan durumları bilme yeteneği ve algıları yansıtır.

Yapı sağlayıcıları, hastayı olumsuz ya da olumlu yönde etkileyebilecek sağlık bakım hizmeti sunanlar ile aile, arkadaş ve yakın çevresinden oluşan sosyal destek gruplarıdır.

\section{Belirsizliği değerlendirme süreci}

Belirsizlik durumuna olumlu veya olumsuz (firsat veya tehlike) bir değer verme ve anlamlandırma.

Uyaran çerçevesi, bilişsel kapasite ve yapı sağlayıcıları gibi bazı öncül değişkenler teorik çerçeveyi belirlemede etkindirler. Bu değişkenler belirsizliğin olumlu veya olumsuz (tehlike veya fırsat) olarak algılanmasına neden olabilir.

Çıkarım, kişisel eğilimler, bilgi, bağlamsal ipuçları ve genel deneyimleri yapılandırı. Kendilerini çevrenin bir parçası olarak görmeleri ve yaşanmış deneyimleri hatırlayarak belirsizliğin değerlendirilmesini ifade eder.

Yanılsama, belirsizlikten kaynaklanan inançların yapısını ifade eder. Değerlendirme sonucunda belirsizlik tehlike ve fırsat olarak değerlendirilir.

\section{Belirsizlikle başa çıkma}

Belirsizlikle baş etmedir. Tehlike, fırsat, baş etme ve uyumu içerir $(6,9)$. Baş etme mekanizmalarının (bilişsel ve davranışsal girişimler) kullanılması, bireyi hastalığın belirsizliğine uyum sağlamaya yönlendirir (6).

Tehlike, olumsuz bir sonucun olasılığıdır.

Firsat, olumlu bir sonucun olasılığıdır.

Hemşirelik girişimleri, hastaların hastalık deneyimi ile baş etme stratejileri için bir süreç geliştirir. Belirsizlik hastalıkların bir parçasıdır ve belirsizliğe bir değer/anlam verilmesi için bu süreç önemlidir. Örneğin, hastalığının tekrarlamasına veya tekrar hastaneye yatmasına odaklanan bir hastaya, hastane ortamını veya kemoterapi tedavilerini hatırlatan özel kokular gibi hatırlatıcılarla baş etme yöntemlerinin öğretilmesi gerekebilir. Baş etme yöntemleri olarak; bilişsel ve davranışsal stratejiler (gevşeme teknikleri, dikkati başka yöne çekme) gibi girişimler uygulanabilir. Bu stratejilerin yanı sıra; hastayı hastalıkları, tedavileri ve yan etkileri konusunda eğitmek, hastalıklarıyla ilgili belirsizlik düzeyini azaltılabilir. Hastanın ailesi ve yakınlarından gelen sosyal destek ile hastanın kaygısının azalması da belirsizliğin azalmasına katkı sağlayabilir. Hastanın kişilik yapısı da hastalığı algılamasında ve hastalık deneyimi ile baş etmesinde olumlu veya olumsuz etki yapabilir. Yaşama dair olumlu kişilik yapısına sahip bireyler hastalığı bir fırsat olarak görüp, yaşamlarını gözden geçirme ve yeniden değerlendirmeyi seçebilir. Yaşam görüşleri olumsuz olan bireyler ise hastalık tanısı aldıktan sonra kaygı düzeyinin artması ile anksiyete ve depresyon deneyimlemeleri yaşam kalitesinde düşüşe yol açabilir $(5-7,9)$.

Hastalıklarda Belirsizlik Kuramı; romatoid artrit (10), AIDS (11), kanser (12-17), kronik hepatit (18), kistik fibroz (19), fibromiyalji $(20,21)$, diyabet (22), Parkinson (23) gibi hastalıklarda kullanılmıştır (11-23). HBK sadece hemşirelik alanında değil, psikoloji gibi diğer alanlarda da kullanılmaktadır $(24,25)$.

Kanser tanısı sonrası başlayan ve tedavi sürecinin farklı aşamaları boyunca hastalar ve ailelerin yaşadıkları sorunların giderilmesi ve yaşam kalitelerinin artırılmasına odaklı hizmet sunulan palyatif bakım ünitelerinde, Hastalıkta Belirsizlik Hemşirelik Kuramı'nın hemşirelik bakım sürecine dahil edilmesinin olumlu sonuçları olacağı düşünülmektedir.

Bu makalede; klinik uygulamada kullanım kolaylığı sağlanması için palyatif bakım ünitesinde kanser tanısı ile yatan bir hastanın "Hastalıkta Belirsizlik Hemşirelik Kuramı"na göre hemşirelik bakımının sunulması amaçlanmıştır.

\section{Olgu sunumu}

Over kanseri tanısı olan 66 yaşındaki S. K. mide bulantısı, kusma, nefes darlığı ve halsizlik yakınmaları nedeniyle devlet hastanesi acil servise başvurmuştur. Hastanın genel durum bozukluğu ve karında asit varlığı nedeniyle dahiliye kliniğine yatışı yapılmıştır. Ancak bulantı ve kusma şiddetinde artma ve genel durumunun daha da kötüleşmesi sonucu hasta; intravenöz (IV) sıVı replasmanı, nazal oksijen tedavisi ve enteral beslenme planıyla palyatif bakım ünitesine yatırılmıştır. 
Hastadan alınan öyküye göre, hastanın 30 yıl boyunca günde bir paket sigara içtiği, hastalığını öğrendikten sonra sigarayı bıraktığı ve hiç alkol kullanmadığı belirlendi. Herhangi bir alerji öyküsü tanımlamayan ve özgeçmişinde bilinen kronik bir hastalığı olmadığı saptanan hastanın iki yıl önce Over Malign Neoplazm tanısı nedeniyle total histerektomi operasyonu geçirdiği belirlendi. Soy geçmişinde bilinen bir özellik yoktu. Eğitim düzeyini, üniversite, mesleğini avukat olarak belirten hasta, hiç evlenmediğini ve evinde yalnız yaşadığını ifade etti. Hastanın yanında bakımına yardımcı olan ücretli bir bakıcısı vardı.

Hastanın bulantı nedeniyle iştahsız olduğu ve yardımla beslendiği gözlendi. Beslenmesinde sulu yumuşak diyet ve günde üç kez $250 \mathrm{ml}$ beslenme solüsyonu verilmeye başlandı. Oral olarak fazla miktarda sıvı alamayan hastaya IV sıvı replasman tedavisi yapıldı. Ağız bakımı yetersiz olan hastada ağız kokusu ve oral mukoz membran hiperemik olarak değerlendirildi. Üriner ve fekal inkontinansı mevcuttu. Hasta giyinme, yeme- içme, yerinden kalkma, yürüme ve hijyen gibi günlük yaşam aktivitelerini yerine getirmede başkasına bağımlıydı. Uyku problemi olan hasta, hastaneye yatmadan önce de iyi uyku uyuyamadığını, sık sık uyandığını, ağrıları nedeniyle derin uykuya dalamadığını, sabah uyandığında kendini dinlenmiş hissetmediğini belirtti. Gözlemlenen süre içinde hastada ağrı yakınması mevcuttu (VAS: 6).

Hastanın beden kitle indeksinin (BKI) 17,5 kg/ $\mathrm{cm}^{2}$ (son üç ayda 11 kilo kaybetmiş), kan basıncının 90/60, nabzının $72 / d k$, Vücut sıcaklığının $36,2^{\circ} \mathrm{C}$, solunum sayısının $13 / \mathrm{dk}$, saturasyonunun \%92 olduğu belirlendi. Yapılan tetkikler sonucunda biyokimyasal kan değerlerin birçoğunun normal değerlerinin altında veya üstünde olduğu görüldü (Tablo 1).

Yapılan fizik muayenesinde karında asit $(+)$ ve pretibial ödem (+++) saptandı. Asit nedeniyle abdominal gerginlik ve deride kuruluk bulunmaktaydı. Kuruluk nedeniyle karın bölgesine nemlendirici losyon sürüldü, düzenli olarak cilt bakımı yapıldı. Hastanın konuşma esnasında dispnesi mevcuttu, yarı oturur pozisyonda yan yatıyordu. Hastaya nazal maske ile oksijen ( $3 \mathrm{lt} / \mathrm{dk}$ ) verilmeye başlandı.

\section{Hemşirelik bakım süreci}

Hasta; acı çektiğini, ama ölmek istemediğini söylüyor ve hemşirelere sürekli olarak "Ben ölecek miyim?" diye soruyordu. Hastalığı ile baş etmeye çalışmadığını ve durumunu kabullendiğini söylemekle birlikte iyileşip ayağa kalkmak istediğini ifade etti. Bu süreci kolaylaştırmak,
Tablo 1. Olgunun laboratuvar bulguları

\begin{tabular}{lcc} 
Tetkik adı & Sonuç & Referans aralığı \\
\hline WBC (Lökosit) & $3,27 \times 10^{3}(\mathrm{~L})$ & $4,5-11 \times 10^{3} / \mathrm{uL}$ \\
PLT (Trombosit) & $112 \times 10^{3}(\mathrm{~L})$ & $150-450 \times 10^{3}$ \\
RBC (Eritrosit) & $3,9 \times 10^{6} / \mathrm{uL}$ & $3,8-5,3 \times 10^{6} / \mathrm{uL}$ \\
Hb (Hemoglobin) & $9,7 \mathrm{~g} / \mathrm{dL}(\mathrm{L})$ & $11,7-16 \mathrm{~g} / \mathrm{dL}$ \\
Htc (Hematokrit) & $30,6 \%(\mathrm{~L})$ & $35-47 \%$ \\
Nötrofil \% & $93,1(\mathrm{H})$ & $45-68 \%$ \\
Lenfosit & $0,26 \times 10^{3}(\mathrm{~L})$ & $1,01-3,3 \times 10^{3}$ \\
Na (Sodyum) & $131 \mathrm{mEq} / \mathrm{L}(\mathrm{L})$ & $136-145 \mathrm{mEq} / \mathrm{L}$ \\
Ca (Kalsiyum) & 8,8 & $8,6-10,2 \mathrm{mg} / \mathrm{dL}$ \\
K (Potasyum) & $4,3 \mathrm{mEq} / \mathrm{L}$ & $3,5-5 \mathrm{mEq} / \mathrm{L}$ \\
Cl (Klorür) & $81 \mathrm{mEq} / \mathrm{L}(\mathrm{L})$ & $96-110 \mathrm{mEq} / \mathrm{L}$ \\
Üre & $63 \mathrm{mg} / \mathrm{dL}(\mathrm{H})$ & $10-50 \mathrm{mg} / \mathrm{dL}$ \\
Kreatinin & $0,58 \mathrm{mg} / \mathrm{dL}$ & $0,3-1 \mathrm{mg} / \mathrm{dL}$ \\
CRP & $8,93 \mathrm{mg} / \mathrm{dL}(\mathrm{H})$ & $0-0,5 \mathrm{mg} / \mathrm{dL}$ \\
SGOT (AST) & $33 \mathrm{U} / \mathrm{L}(\mathrm{H})$ & $<31 \mathrm{U} / \mathrm{L}$ \\
SGPT (ALT) & $21 \mathrm{U} / \mathrm{L}$ & $<34 \mathrm{U} / \mathrm{L}$ \\
Total Protein & $6,3 \mathrm{mg} / \mathrm{dL}(\mathrm{L})$ & $6,4-8,3 \mathrm{mg} / \mathrm{Dl}$ \\
Amilaz & $68 \mathrm{U} / \mathrm{L}$ & $28-100 \mathrm{U} / \mathrm{L}$ \\
& &
\end{tabular}

hastanın sağlıklı tepkilerle ve daha güçlenerek hastalığı ile baş etmesini sağlamak amacıyla hastalığı nedeniyle yaşadığı belirsizlik durumu HBK'na göre belirlenen sorunlarına yönelik hemşirelik bakım süreci yönetilmiştir (Şekil 2).

Yapılan gözlem ve değerlendirmeler sonucunda hastada belirlenen Kuzey Amerika Hemşirelik Tanıları Birliği (North American Nursing Diagnosis Association (NANDA) hemşirelik tanıları aşağıdaki gibi sıralanabilir:

1. Fiziksel mobilitede bozulma

2. Öz bakım eksikliği

3. Deri bütünlüğünde bozulma riski

4. Oral mukoz membranda bozulma

5. Gereksinimden az beslenme

6. Sivı-elektrolit dengesizliği

7. Yutmada bozukluk/aspirasyon riski

8. Kanama riski

9. Düşme riski

10.Travma riski

11.Uyku örüntüsünde rahatsızlık

12. Yorgunluk

13.Bilgi eksikliği

14. Bireysel baş etmede yetersizlik

15.Duyusal algılamada bozulma 


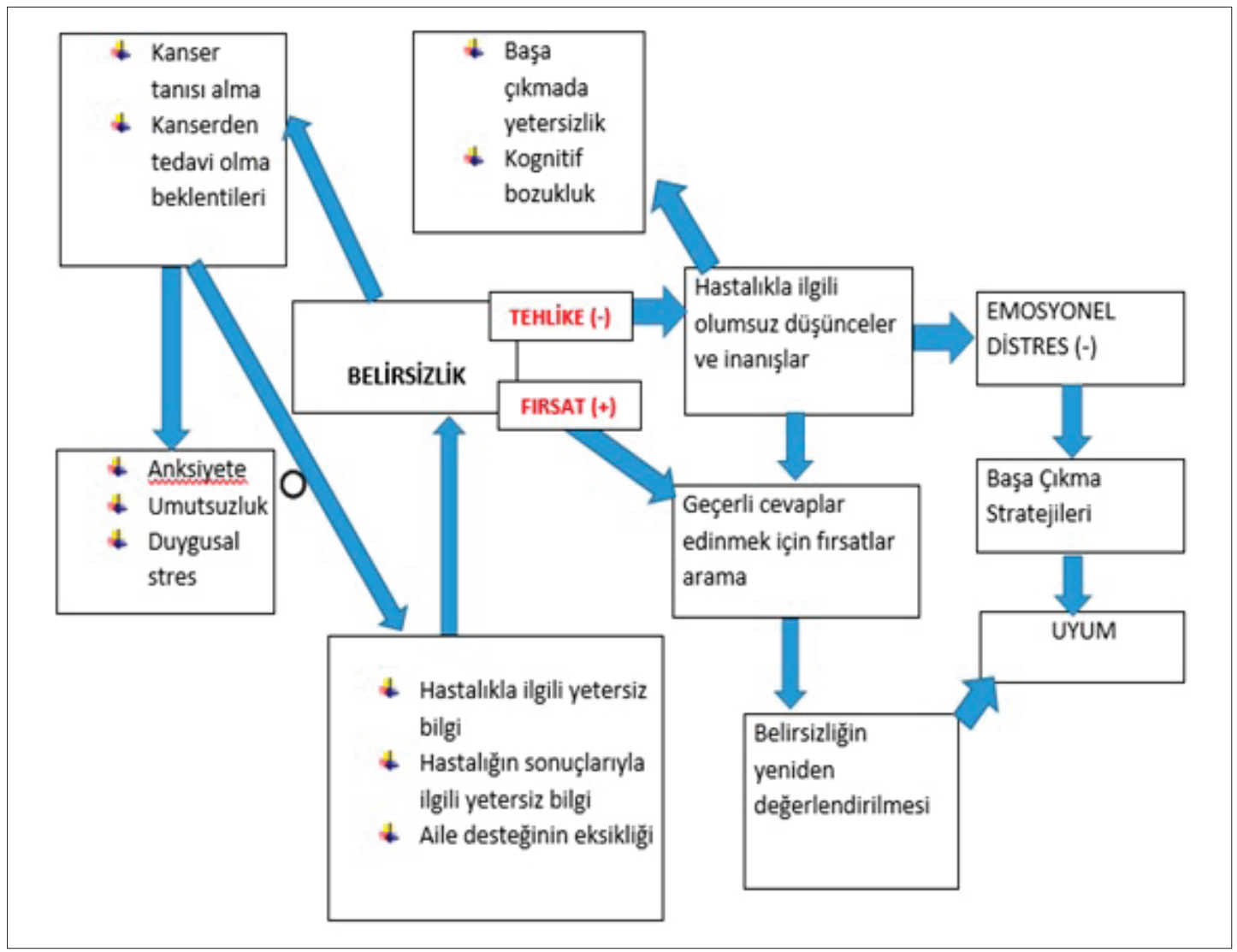

Şekil 2. Olgunun HBK'na göre bakım modeli.

$\mathrm{Bu}$ makalede tüm hemşirelik tanılarına yer verilememiş olup, HBK ile ilişkili hemşirelik tanıları ele alınmıştır.

Kanser tanısı aldıktan sonra hastalığın belirsizliği ve tedavilerin zorluğu nedeniyle anksiyete, umutsuzluk ve korku deneyimleyen hasta, kaygı düzeyinin artış nedeniyle yaşam kalitesinde azalma olduğunu belirtti. Belirsizlik nedeniyle sonunun ne olacağını bilmediğini, kanserle baş edemeyeceğini, bu hastalıktan kurtuluş olmadığı gibi olumsuz inanışları olan hasta hastalığı, tedavisi ve prognozu ile ilgili bilgi sahibi olmadığını ifade etti. Aynı zamanda sosyal destek eksikliği nedeniyle hastanın belirsizliği olumsuz olarak algılayarak tehlikeye dönüştürdüğü saptandı.

Hemşirelik Tanısı: Hastalık sürecindeki belirsizliğe bağlı Bilgi Eksikliği

Beklenen Sonuç: Belirsizlikle ilgili geçerli cevaplar bulma ve belirsizliği fırsata dönüştürerek planlanan tedaviye uyum sağlaması.

Girişimler: Hastanın belirsizliğini azaltmak için; hastanın endişelerini ifade etmesine olanak sağlayan öneri ve yaklaşımlarda bulunuldu. Hastayla açık, güvenilir ve etkili bir iletişim kuruldu. Hastayı güçlendirmek, korkularını anlamak, belirsizliğe açıklık getirmek ve yön bulmak için hastanın bilgi eksikliğine yönelik hastanın eğitim düzeyine uygun olarak hastalık, tedavi ve yan etkileri hakkında hastaya sözel ve görsel materyallerle kısa ve net bilgilerle eğitim verildi. Hasta yakınlarının hastayı sık aralıklarla ziyaret etmeleri ve hasta için gerekli destekleyici bilgileri vermeleri sağlandı.

Değerlendirme: Belirsizliği bir tehlike olarak algılayan ve hastalığı ile ilgili olumsuz görüş ve inanışları olan hastanın belirsizliği yeniden değerlendirmesi sağlandı. Tedavisi yapılırken isteksiz olan ve tedavinin gerekli olmadığını ifade eden hasta, bilgi eksikliğine yönelik verilen eğitim ve destek ile gerçekleştirilen hemşirelik girişimleri sonucunda tedavi sırasında daha uyumlu ve istekli olduğu gözlendi. İyileşmek için bu tedavilerin yapılması gerektiğini kabul ettiğini ifade etti.

Hemşirelik Tanısı: Hastalıkla ilgili olumsuz düşünce ve inanışlara bağlı yaşadığı anksiyete, korku ve distres yönetiminde yetersizliğe bağlı olarak Bireysel Baş Etmede Yetersizlik. 
Beklenen Sonuç: Kendisinin de çevrenin bir parçası olduğunu kabullenmesi ve hastalığı deneyimlerken belirsizliği anlamlandırmada etkili bireysel başa çıkma davranışı geliştirmesi.

Girişimler: Hastanın tehlike olarak gördüğü ölüm, kaos ve bağımlılık algısını ifade etmesine olanak sağlayan etkili ve aktif bir iletişim kuruldu. Hastanın hastalığı ile baş etmede yetersizliğini gidermek için tehlikeyi fırsata dönüştürmesinde etkili müdahaleler (gevşeme teknikleri) uygulandı. Dikkatini başka yöne çekmek için hastaya kitap okundu, müzik dinletildi ve hayal kurması telkin edildi. Hastanın evli ve çocuk sahibi olmaması ve ailesinden olmayan bir bakıcı tarafından bakılması nedeniyle hastada sosyal destek sistemi eksikliği mevcuttu. Bu durum hastanın hastalığına karşı daha olumsuz görüşe sahip olmasına neden olmaktaydı. Hastanın izniyle ailesinden kardeşi ve arkadaşları ile iletişime geçildi.

Değerlendirme: Hemşire-hasta iletişiminde güvene dayalı bir ilişki kurularak güvenilir otorite ile fırsatların yapılanması sağlandı. Hasta; hayatındaki öncelikleri yeniden yapılandırması, yaşamına yeni bir perspektif kazandırması ve hastalığını anlamlandırması konusunda cesaretlendiğini ifade etti. Hastanın ailesi ve yakınlarından gelen sosyal destek ve hemşirelerin etkili iletişimi sayesinde kaygısının ve belirsizliğin azaldığını belirtti.

Hemşirelik Tanısı: Belirsizlik nedeniyle hastalığa ve tedaviye uyum sağlamada zorluğun yol açtığı emosyonel distrese bağlı Duyusal Algılamada Bozulma.

Beklenen Sonuçlar: Hastalığa ve tedaviye uyum göstermesi ve emosyonel rahatlama sağlaması.

Girişimler: Tedavilerin karmaşıklığı, hastanın bağımlılık düzeyinin artması, yaşam kalitesinde düşüş olması, öngörülemeyen yaşam beklentisi ve hastalığı anlamlandıramamanın hastada emosyonel bir stres yarattığı gözlendi. Hastanın duygusal algılamasında bozulma, spiritüel distres yaşamasına neden olan bu durum hastalığa uyum göstermesinde bir engeldi. Hastanın distres düzeyi National Comprehensive Cancer Network (NCCN) Distres Termometresi ile değerlendirildi. NCCN Distres
Termometresi; hastaların öznel ifadeleri ile 1'den 10'a kadar puanlanan ve 5 ve üzeri puanın distres varlığını gösteren bir değerlendirme aracıdır $(26,27)$. Hastanın distres termometresini puanlaması istendiğinde, yaşadığı distres düzeyini 7 puan olarak ifade etti.

Hastanın hastalığa, tedaviye, bakım sürecine uyum göstermesi için; hastalık, belirsizlik, değer biçme, başa çıkma ve uyum sağlaması için psikososyal bakım verildi. Hastanın kanser tanısı alması ve tedaviden beklentisi olmamasının yol açtığı anksiyete ve umutsuzluk distres kaynağı olarak saptanmıştır. Aile desteğinde eksiklik ve kanserle baş etmede yetersizlik hastanın belirsizlik yaşamasına neden olmuştur. Hastanın belirsizliğin yol açtığı anksiyetesi ile baş etmesi için gevşeme tekniklerinden; solunum ve gevşeme egzersizleri anksiyeteyi azaltmada hemşirelik girişimi olarak kullanılmıştır.

Değerlendirme: Psikososyal faktörlerin belirlenmesi ve hemşire ile hasta arasında güvene dayalı etkili bir iletişim kuruldu. Bir hafta sonra hastanın deneyimlediği korku, anksiyete ve distres düzeyinde azalma belirlendi. Hastanın distres termometresini puanlaması istendiğinde, yaşadığı distres düzeyini 4 puan olarak ifade etti. Önceki görüşmelerde hastalığını yaşamın sonu olarak niteleyen hasta, bu durumun düzelebileceğine inancı olduğunu ve yaşamının geri kalanı için umutlu olduğunu ifade etti.

\section{Sonuç}

Kansere ilişkin belirsizlik yönetiminin hedeflendiği HBK'na göre verilen holistik ve destekleyici hemşirelik bakım süreci; kanser olgusunun hastalığını "ikinci bir şans" olarak yeniden anlamlandırdığını, başa çıkma stratejileri ile yaşadığı korku, belirsizlik ve anksiyete ile baş etme mekanizmalarını geliştirmesi sağlanmıştır. Hemşirelik bakımında kullanılan HBK ile belirsizliği azaltmak için bilgi eksikliğine yönelik hastaya eğitimi, belirsizliği yönetmek için de baş etme stratejileri geliştirilmesi, uygulanması ve değerlendirilmesi ile etkin sonuçlara varılabilir. Bu kapsamda hemşirelik bakımında Mishel'in modelinin kullanılması sonucunda; hastanın psikososyal uyumu, tıbbi bakımdan memnuniyeti, hastalıkla ilgili yeterli bilgi sahibi olması ve yaşam kalitesi düzeyi ölçülebilir. 


\section{Kaynaklar}

1. Özçelik H, Fadıloğlu Ç, Karabulut B, Uyar M, Elbi H, Eyigör $S$, et al. Kanser Hastasının Palyatif Bakımında Vaka Yönetimine Dayalı Multidispliner Bakım Protokolü. Ağrı Derg 2014;26:47-56. [CrossRef]

2. Sepúlveda C, Marlin A, Yoshida T, Ullrich A. Palliative Care: The World Health Organization's Global Perspective. J Pain Symptom Manage 2002;24:91-6. [CrossRef]

3. Dünya Sağlık Örgütü (WHO) . WHO Definition of Palliative Care. http://www.who.int/cancer/palliative/definition/en/

4. Karabacak Ü, Acaroğlu R. Konfor Kuramı. Maltepe Üniversitesi Bilim ve Sanat Derg 2011;4:197-202.

5. Bailey DE, Stewart JL. Uncertainty in illness theory. In: Alligood MR, Tomey AM, editors. Nursing Theorist and Their Work. New York: Mosby-Elsevier; 2010. pp.599-617.

6. Mishel MH. Uncertainty in illness. Image J Nurs Sch 1988;20:225-32. [CrossRef]

7. Barron CR. Stress, Uncertainty, and Health. In: Rice VH, editor. Handbook of Stress, Coping, and Health: Implications for Nursing Research, Theory, and practice. Thousand Oaks, CA: Sage Publications; 2000. pp.517-39.

8. Neville KL. Uncertainty in illness: an integrative review. Orthop Nurs 2003;22:206-14. [CrossRef]

9. Mishel MH. Reconceptualization of the Uncertainty in IIIness Theory. Image J Nurs Sch 1990;22:256-62. [CrossRef]

10. Braden CJ. A test of the self-help model: learned response to chronic illness experience. Nurs Res 1990;39:42-7. [CrossRef]

11. Regan-Kubinski MJ, Sharts-Hopko N. Illness cognition of HIV-infected mothers. Issues Ment Health Nurs 1995;16:327-44. [CrossRef]

12. Lee $\mathrm{YL}$, Gau BS, Hsu WM, Chang HH. A model linking uncertainly, post-traumatic stress and health behaviors in childhood cancer survivors. Oncol Nurs Forum 2009;36:E20-30. [CrossRef]

13. Lien C, Chen S, Tsai P, Chen K, Hsieh Y, Liang Y. Effectiveness of nursing instruction in reducing uncertainty, anxiety and self-care in breast cancer women undergoing initial chemotherapy. Hu Li Za Zhi 2010;57:51-60.

14. Sammarco A, Konecny LM. Quality of life, social support, and uncertainty among latina and caucasian breast cancer survivors: a comparative study. Oncol Nurs Forum 2010;37:93-9. [CrossRef]

15. Kazer MW, Bailey DE, Sanda M, Colberg J, Kelly WK. An internet intervention for management of uncertainty during active surveillance for prostate cancer. Oncol Nurs Forum 2011;38;561-8. [CrossRef]
16. Lien CY, Lin HR, Kuo IT, Chen ML. Perceived uncertainty, social support and psychological adjustment in older patients with cancer being treated with surgery. J Clin Nurs 2009;18:2311-9. [CrossRef]

17. Clayton MF, Mishel MH, Belyea M. Testing a model of symptoms, communication, uncertainty, and well-being, in older breast cancer survivors. Res Nurs Health 2006;29:18-39. [CrossRef]

18. Bailey D, Barroso J, Muir A, Sloane R, Richmond J, McHutchison J, et al. Patients with chronic hepatitis $C$ undergoing watchful waiting: Exploring trajectories of illness uncertainly and fatigue. Res Nurs Health 2010;33:465-73. [CrossRef]

19. Tluczek A, McKechnie AC, Lynam PA. Modified uncertainty theory and parents' perspectives about equivocal diagnostic results for cystic fibrosis. Qual Health Res 2010;20:209-23. [CrossRef]

20. Anema C, Johnson M, Zeller JM, Fogg L, Zetterlund J. Spiritual wellbeing in individuals with fibromyalgia syndrome: relationships with symptom pattern variability, uncertainty, and psychosocial adaptation. Res Theory Nurs Pract 2009;23:8-22. [CrossRef]

21. Reich JW, Johnson LM, Zautra AJ, Davis MC. Uncertainty of illness relationships with mental health and coping processes in fibromyalgia patients. J Behav Med 2006;29:307-16. [CrossRef]

22. Landis BJ. Uncertainty, spiritual well-being, and psychosocial adjustment to chronic illness. Issues Ment Health Nurs 1996;17:21731. [CrossRef]

23. Sanders-Dewey NEJ, Mullins LL, Chaney JM. Coping style, perceived uncertainty in illness, and distress in individuals with Parkinson's disease and their caregivers. Rehabil Psychology 2001;46:363-81. [CrossRef]

24. Mishel M. Uncertainty of Illness. https://sites.google.com/a/ northgeorgia.edu/merle-mishel-middle-range-nursing-theorist/ home/uncertainty-of-illness

25. Mishel M, Sorenson D. Uncertainty in Gynecological Cancer: A Test of the Mediating Functions of Mastery and Coping. Nurs Res 1991;40:167-71. [CrossRef]

26. Holland JC, Andersen B, Breitbart WS, Compas B, Dudley MM, Fleishman S, et al. NCCN Distress Management, Clinical Practice Guidelines in Oncology. J NCCN 2010;8:448-85. http://www. aftercancer.co/wp-content/uploads/2015/11/NCCN-Distressmanagement-guidelines.pdf

27. NCCN. Distress Management for Patients. Version 1.2017.https:// www.nccn.org/patients/guidelines/content/PDF/distress-patient. pdf 